\title{
Резистентність бактерій до хлоргексидину, який використовують у хірургічній стоматології
}

\author{
А.Г. Салманов ${ }^{1}$, Т.П. Бондар², В.Д. Чопчик² \\ 'Національний університет охорони здоров'я України імені П.Л. Шупика, Київ, Україна \\ ${ }^{2}$ Стоматологічний медичний центр Національного медичного університету імені О.О. Богомольця, Київ, Україна
}

\begin{abstract}
Анотація. Антисептичні засоби все частіше використовують для гігієни рук та деколонізації шкіри як ключовий інструмент для профілактики інфекцій, пов'язаних з охороною здоров'я. Хлоргексидин, двовалентний катіонний бігуанід, має широкий спектр активності і $€$ одним з найбільш часто використовуваних місцевих антисептичних засобів. Примітно, що відмічається все більша кількість досліджень, які повідомляють про зниження рівня сприйнятливості до хлоргексидину. На відміну від бактеріальної стійкості до антибіотиків, використання таких параметрів, як мінімальна інгібуюча концентрація, для визначення стійкості до антисептиків, включаючи хлоргексидин, не $\epsilon$ простим. Для виявлення зниженої сприйнятливості до хлоргексидину використано низку методів, але, що важливо, немає стандартизованого методу та відсутня єдина думка щодо визначення резистентності до хлоргексидину. У цьому огляді проведено оцінку наявних методів виявлення зниженої сприйнятливості до хлоргексидину та поширеності сили стійкості до інших антимікробних агентів. Було зосереджено увагу на розвитку зниженої сприйнятливості до хлоргексидину та наявності efflux-опосередкованих генів стафілококів, і розглянуто клінічну значимість цього явища. Нарешті, ми виділили питання без відповіді, щоб покращити розуміння цієї нестабільної загрози. Передбачаємо, що клінічне застосування хлоргексидину продовжуватиме збільшуватися, і важливо бути уважним щодо можливості того, що це може призвести до появи нових клонів зі зниженою сприйнятливістю. Невибіркове використання хлоргексидину за відсутності даних про ефективність не слід рекомендувати.
\end{abstract}

Ключові слова: хлоргексидин; інфекція, пов'язана з наданням медичної допомоги; хірургічна стоматологія; патогени; антимікробна резистентність.

\section{Вступ}

Незважаючи на очевидні досягнення медичної науки та впровадження новітніх технологій для діагностики та лікування хворих, кількість випадків інфекцій, пов'язаних з наданням медичної допомоги (ІПМД), у світі не зменшується. Експерти Всесвітньої організації охорони здоров'я пов'язують зниження ефективності заходів боротьби з ІПМД з появою та поширенням мікроорганізмів, резистентних до дії протимікробних препаратів, зокрема антисептиків.

Гігієна рук - один із важливих елементів у комплексі заходів, спрямованих на боротьбу з ІПМД. На сьогодні визначено 3 рівні обробки рук медичних працівників для обеззараження: 1) миття рук із застосуванням звичайного твердого чи рідкого мила та проточної води для усунення бруду, пилу, різноманітних органічних речовин, 2) гігієнічна (Європа)/антисептична (США) обробка рук, тобто очищення шкіри рук із використанням протимікробного/бактерицидного мила та води, 3) гігієнічна дезінфекція рук (Європа), яка проводиться із застосуванням засобу на спиртовій основі, що наноситься на суху шкіру рук без води. Для обробки рук перед хірургічним втручанням застосовують 2 методики: а) хірургічне миття (Європа) або хірургічна обробка рук (США), тобто очищення шкіри рук протимікробним милом та водою, б) хірургічна дезінфекція рук (Європа), тобто обробка шкіри рук із застосуванням засобу на спиртовій основі, який наноситься на суху шкіру рук без води [1].

Загальновідомо, що руки медичного персоналу відіграють провідну роль у передачі резистентних штамів мікроорганізмів. У процесі роботи у хірургічному стаціонарі поверхня рук медичного персоналу може бути неодноразово контамінована потенційними мікроорганізмами - збудниками ІПМД. Тому навіть якщо медичний персонал працює в рукавичках, зберігається небезпека інфікування пацієнтів та інших медичних працівників. Руки медичного персоналу - один із основних факторів передачі збудників ІПМД. Тому гігієна рук $\epsilon$ одним із важливих елементів у комплексі заходів, спрямованих на боротьбу з ІПМД. Майже $1 / 3$ випадків ІПМД класифікують як такі, яких можна запобігти шляхом дотримання вимог гігієни рук, яка досягається за допомогою ефективних антисептиків [1].
На сьогодні в Україні для гігієни рук використовують безліч антисептиків, серед яких найбільш поширені препарати хлоргексидину; ефективність боротьби з резистентними штамами мікроорганізмів в Україні не вивчено. Це потребує врегулювання заходів щодо попередження поширення резистентних мікроорганізмів на основі світового досвіду з питань гігієни рук.

Мета дослідження: проаналізувати результати наукових досліджень та оцінити ефективність препаратів хлоргексидину в попередженні передачі резистентних бактерій - збудників нозокоміальних інфекцій.

\section{0б'єкт і методи дослідження}

За даними світової літератури, проаналізовано результати наукових досліджень з питань антисептиків, які використовують для забезпечення гігієни рук медичного персоналу відділень хірургічного профілю закладів охорони здоров'я. До огляду включено результати 75 робіт. Пошук матеріалу здійснювали за допомогою всесвітньої мережі Internet в електронних базах даних Medline, PubMed, Всесвітньої організації охорони здоров'я, Національної медичної бібліотеки України та Національної бібліотеки України імені B.І. Вернадського.

\section{Результати та їх обговорення}

Гігієна рук вважається найважливішим елементом контролю ІПМД ще відтоді, коли І. Зіммельвейс встановив вплив цієї процедури на частоту випадків породільної лихоманки [1-4]. Проте рівень дотримання вимог до гігієни рук згідно з даними різних дослідників коливається в межах $16-81 \%$, в середньому $40 \%[5,6]$.

Одним із найбільш поширених антисептиків для гігієни рук медичного персоналу $\epsilon$ хлоргексидин, який належить до катіонних бігуанідів та визнаний у якості речовини з протимікробними властивостями в 1954 р. Він існує у формі солі ацетату (діацетату), глюконату та гідрохлориду $[7,8]$. Хлоргексидину біглюконат катіонна речовина, несумісна з детергентами, які включають аніонні групи, з милами, лугами, натрію лаурилсульфатом, натрію карбоксиметилцелюлозою й альгінатом. Сумісний із препарата- 
ми, що включають катіонні групи (бензалконію хлорид, центримонію бромід).

Хлоргексидину глюконат для дезінфекції шкіри часто застосовують у концентрації 0,5-0,75\% у формі водного розчину або у складі деяких мийних засобів, а також в концентрації 2-4\% у складі мийних засобів [9]. Його активність значно знижується за наявності органічних речовин, натуральної кірки, а також кремів для рук, які містять аніонні речовини для утворення емульciї $[7,10,11]$. Втрата активності хлоргексидину може призвести до контамінації 0,1\% розчинів, наприклад, різними видами бактерій Pseudomonas [12].

Протимікробна активність хлоргексидину залежить від його концентрації. При нижчій концентрації хлоргексидин забезпечує бактеріостатичний вплив на більшість грампозитивних бактерій та на багатьох грамнегативних бактерій [13].

При концентрації хлоргексидину $\geq 20$ мкг/мл можна очікувати на бактерицидну дію [14]. Фактична ефективна концентрація щодо Staphylococcus aureus (S. aureus) коливається в межах 0,0040,4\%, при цьому час впливу для знищення клітин також колива$\in$ ться в межах від <15 до >360 хв [15].

Згідно $з$ даними більшості досліджень, концентрація для швидкої інактивації повинна набагато перевищувати рівень мінімальної гальмівної концентрації, що підтверджено для S. aureus та Escherichia coli (E. coli) [16, 17]. У складі рідкого мила хлоргексидин, як правило, використовується в концентрації 4\% та забезпечує бактерицидну активність щодо різних грамнегативних та грампозитивних бактерій $[18,19]$.

Результати суспензійних тестів хлоргексидину (4\%), отримані в ході порівняльних досліджень, свідчать про те, що він забезпечує ефективність щодо метицилінрезистентного S. aureus (methicillin-resistant S. aureus - MRSA) меншу, ніж щодо чутливих до метициліну штамів S. aureus, через що виникли сумніви в доречності застосування цієї діючої речовини для попередження поширення MRSA [20]. Саме такий результат отримано і при перевірці ентерококів. Суспензійні тести 4\% хлоргексидину свідчать про особливо низьку активність щодо різних видів Enterococcus та ванкоміцинрезистентних ентерококів (vancomycin-resistant Enterococcus - VRE) при усуненні етапу нейтралізації залишкової активності [21].

Порівняно з продуктами для миття рук, які не містять лікарських речовин, засоби з хлоргексидином забезпечують менше скорочення кількості різноманітних бактерій, резистентних до антибіотиків, таких як MRSA, VRE, або резистентних до гентаміцину ентерококів [22]. Порівняно з іншими діючими речовинами хлоргексидин $\epsilon$ менш ефективним щодо різних нозокоміальних патогенних мікроорганізмів, ніж бензалконію хлорид або повідон-йод [23].

$\epsilon$ повідомлення про те, що миття рук протягом 1 хв милом, яке містить 4\% хлоргексидину, забезпечує на штучно контамінованій шкірі рук середнє зменшення кількості E. coli на $3,08 \log _{10}$ од. [24]. У практичних умовах при штучній контамінації шкіри рук штамами MRSA рідке мило з вмістом хлоргексидину забезпечувало таку саму ефективність, що і звичайне мило [25]. Такий самий результат відмічали при контамінації шкіри рук штамами $S$. aureus [26]. Скорочення в межах 2,1-3 $\log _{10}$ од. відмічали при забрудненні рук різними видами Klebsiella після 20-разового миття рук милом, яке містить 4\% хлоргексидину [27]. Під впливом хлоргексидину в 4\% концентрації кількість резидентної мікрофлори шкіри рук скорочується в межах 0,35-2,29 $\log _{10}$ од. залежно від тривалості експозиції.

У ході іншого клінічного дослідження медичні працівники нейрохірургічного відділення та відділення судинної хірургії оцінювали результати застосування звичайного мила та рідкого мила з 4\% вмістом хлоргексидину. Встановлено, що контамінація шкіри рук була вірогідно меншою після використання звичайного мила, ніж при використанні мила з хлоргексидином [28].

Миття рук милом з 4\% вмістом хлоргексидину згідно з повідомленням $\epsilon$ більш ефективним за показниками зменшення загальної кількості бактерій, ніж милом з 1\% вмістом трикло- зану [29]. За результатами дослідження використання звичайного мила та мила з 4\% вмістом хлоргексидину медичними працівниками двох хірургічних відділень визначено, що звичайне мило $\epsilon$ вірогідно більш ефективним, ніж мило з хлоргексидином, у зменшенні кількості бактерій на шкірі рук працівників [28].

Після контамінації шкіри рук різними видами Klebsiella spp. виявлено скорочення кількості життєздатних штамів на $98 \%$ при застосуванні мила з 4\% вмістом хлоргексидину, що дорівнює зменшенню майже на $2 \log _{10}$ од. [26]. Встановлено, що хлоргексидин не усуває з рук MRSA, тоді як знешкодження грамнегативних бактерій при застосуванні хлоргексидину $\epsilon$ дуже ймовірним [28]. Середні показники вмісту резидентної мікрофлори на руках хірургів після 3-хвилинної обробки 4\% хлоргексидином знижувалися 33,5 (до операції) до $3,15 \log _{10}$ од. (після операції) при проведенні операцій тривалістю <2 год. Доведено, що при проведенні операцій тривалістю >3 год 4\% хлоргексидин не здатен забезпечити зниження рівня резидентної мікрофлори на початковому рівні (4,5 до та 5,2 після операції) [29].

Визначення резистентності до хлоргексидину часто ґрунтується на даних дослідження 1982 р., в ході якого визначали значення мінімальної інгібуючої концентрації (МІК) хлоргексидину відносно 317 клінічних ізолятів Pseudomonas aeruginosa (P. aeruginosa). Дослідники дійшли висновку, що про резистентність до хлоргексидину свідчить резистентність при МІK $\geq 50$ мг/л [30].

Резистентність до хлоргексидину різних видів грампозитивних бактерій відмічають нечасто. Не виявлено резистентності до хлоргексидину різних видів Streptococcus та Enterococcus, тоді як у грамнегативних бактерій, таких як E. coli, Proteus mirabilis (P. mirabilis), Providencia stuartii, P. aeruginosa, Pseudomonas cepacia та Serratia marcescens (S. marcescens), резистентність до хлоргексидину спостерігається часто [14, 30-36]. Частота поява резистентних штамів коливається залежно від виду мікроорганізмів. Загалом 84,6\% клінічних ізолятів P. mirabilis слід вважати резистентними до хлоргексидину. Для інших грамнегативних бактерій цей показник $\epsilon$ нижчим [31].

$\epsilon$ повідомлення про набуття резистентності до хлоргексидину штамами S. aureus, а також штамами багатьох грамнегативних бактерій, виділених після регулярних промивань сечового міхура розчином, який містив 600 мг хлоргексидину на 1 л, або після додавання хлоргексидину в катетерні мішки пацієнтів із паралічем нижніх кінцівок [19, 37-39]. Деякі з ізолятів характеризувалися дуже високим рівнем резистентності, навіть при МІК $\geq 500$ мг/л. Резистентність до хлоргексидину притаманна лише госпітальним ізолятам. Перевірка 196 ізолятів грамнегативних бактерій, виділених не в лікарні, не виявила резистентності до хлоргексидину [40].

Високе значення МІК хлоргексидину корелює з низькими показниками зменшення кількості життєздатних бактерій при проведенні суспензійних тестів, що $\epsilon$ свідченням потенційної загрози. Відмічається як резистентність до однієї речовини, так $\mathrm{i}$ перехресна резистентність до інших знезаражувальних речовин [41]. За результатами дослідження штамів P. aeruginosa, виділених у промислових умовах і лікарнях, визначено зв'язок між резистентністю до антибіотиків та хлоргексидину [39]. Тому рекомендують ретельно розглянути можливість виникнення перехресної резистентності до антисептичних засобів і антибіотиків. Різні грамнегативні бактерії, що не викликають бродіння, які виділено зі зразків крові пацієнтів із онкологічними захворюваннями, вдалося позбавити життєздатності розчином, який містив $>500$ мг хлоргексидину на 1 л [42].

Визначено декілька механізмів розвитку резистентності. Набута резистентність, ймовірно, зумовлена змінами внутрішніх або зовнішніх мембран клітин бактерій, поверхні клітин або клітинної стінки [43-45]. Вона може пояснюватися також наявністю плазміду, який кодує резистентність до хлоргексидину, здатного до передачі іншим видам бактерій [46]. Зміну вмісту ліпідів або зниження адсорбції антисептичного засобу можна виключити з переліку головних шляхів розвитку резистентності, що доведено результатами дослідження штамів P. mirabilis та S. marcescens, 
виділених у пацієнтів з інфекційними захворюваннями сечовивідних шляхів, збудниками яких були ці види [47].

Багаторазовий вплив хлоргексидину на бактерії може призводити до їх адаптації, що підвищує рівень резистентності. Цей феномен доведено результатами дослідження S. marcescens. Один з прикладів цього явища відмічали при багаторазовому контакті культури з розчинами для контактних лінз, які містили 0,001-0,006\% хлоргексидину, після чого клітини S. marcescens були здатні до розмноження в дезінфікуючому розчині [48].

Багаторазовий вплив 5 г хлоргексидину на 1 л розчину на клітини P. aeruginosa призводив до зростання MIK з $<10$ до 70 мг/л протягом 6 днів [35]. Такий самий результат виявлено в дослідженні Pseudomonas stutzeri, які набували резистентності (МІК 50 мг/л) після 12-денної експозиції [49]. Навіть для Streptococcus sanguis відмічено безсумнівне підвищення МІК хлоргексидину після тривалої експозиції [50].

Загалом вищий рівень впливу хлоргексидину в лікарнях призводить до підвищення резистентності [71]. Нещодавно з'явилося повідомлення про те, що деякі штами P. aeruginosa, Klebsiella pneumoniae та Acinetobacter baumannii, виділені з дозаторів для рідкого мила, здатні до розмноження в рідкому милі, яке містить 2\% хлоргексидин, при розведенні 1:2; ATCС штами Klebsiella pneumoniae та Acinetobacter baumannii розмножувалися і при вищій концентрації [51]. Це повідомлення свідчить про потенційну загрозу для закладів охорони здоров'я.

Резистентність до хлоргексидину може призвести навіть до спалаху нозокоміальних інфекцій. Аналіз причин випадків спалахів ІПМД свідчить про контамінацію розчинів хлоргексидину. $\epsilon$ повідомлення про те, що при використанні медичним персоналом 0,5\% розчину хлоргексидину для дезінфекції затискачів для лінії Хікмана відбулося перенесення адаптованих до хлоргексидину бактерій на внутрішньовенні лінії, що призвело до 12 випадків бактеріємії, 3 з яких були летальними [52].

Під час іншого спалаху контамінація дезінфікуючого розчину мікроорганізмами стала причиною 9 випадків інфекційних уражень за місцем хірургічного втручання [75]. Ризик виникнення ІПМД, збудниками яких $\epsilon$ види, резистентні до хлоргексидину, особливо високий при застосуванні антисептичних засобів для рук на основі хлоргексидину у випадках, коли резистентність до хлоргексидину $є$ властивою грамнегативним бактеріям [53].

\section{Висновок}

У результаті аналізу літературних даних встановлено можливість формування резистентності бактерій - збудників ІПМД до препаратів хлоргексидину, який використовують для забезпечення гігієни рук. Незважаючи на наявність значної кількості літературних джерел, найефективніший комплекс заходів щодо боротьби з резистентністю, що базується на доказових даних і може застосовуватися у закладах охорони здоров'я будь-якого типу, визначити не вдалося. Це пояснюється, перш за все, розбіжностями в методиках вивчення та результатах, отриманих при застосуванні різних профілактичних заходів. По-друге, відсутність контрольних тестів унеможливлює порівняння різних заходів або стратегій з контролю за поширенням резистентності до антисептиків. Крім того, інформація, що наводиться у вищезазначеній літературі, має здебільшого описовий і частково експериментальний характер. Тому $\epsilon$ доцільними організація та проведення систематичного моніторингу за розвитком і поширенням резистентності мікроорганізмів збудників ІПМД до препаратів хлоргексидину. Це дозволить внести відповідні зміни до заходів, спрямованих на профілактику передачі резистентних мікроорганізмів через руки медичного персоналу.

\section{Список використаної літератури}

1. Салманов А.Г. (2011) Оптимізація забезпечення гігієни рукмедичного персоналу хірургічних стаціонарів. Укр. мед. часопис, 2(82): 85-91.

2. Haley R.W., Culver D.H., White J.W. et al. (1985) The efficacy of infection surveillance and control programs in preventing nosocomial infections in US hospitals. Am. J. Epidemiol., 121: 182-205. doi: 10.1093/oxfordjournals.aje.a113990.
3. Nystrom B. (1994) Impact of handwashing on mortality in intensive care: examination of the evidence. Infect. Control Hosp. Epidemiol., 15(7): 435-436. doi: 10.1086/646947.

4. Reybrouck G. (1983) Role of hands in the spread of nosocomial infections. J. Hosp. Infect. 4(2): 103-110. doi: 10.1016/0195-6701(83)90040-3.

5. Rotter M., Skopec M. (2003) Entwicklung der Händehygiene und die Bedeutung der Erkenntnisse von Ignaz Ph. Semmelweis, p. 1-27. In: G. Kampf (Ed.), Hände-Hygiene im Gesundheitswesen. Springer-Verlag KG, Berlin, Germany.

6. Pittet D. (2000) Improving compliance with hand hygiene in hospitals. Infect. Control Hosp. Epidemiol., 21(6): 381-386. doi: 10.1086/501777.

7. Boyce J.M., Pittet D. (2002) Guideline for hand hygiene in health-care settings. Recommendations of the healthcare infection control practices advisory committee and the HICPAC/ SHEA/APIC/IDSA hand hygiene task force. Morb. Mortal. Wkly. Rep., 51: 1-45.

8. Russell A.D. (1986) Chlorhexidine: antibacterial action and bacterial resistance. Infection, 14(5): 212-215. doi: 10.1007/BF01644264.

9. Lowbury E.J., Lilly H.A. (1973) Use of 4 per cent chlorhexidine detergent solution (Hibiscrub) and other methods of skin disinfection. Br. Med. J., 1(5852): 510-515. doi:10.1136/ bmj.1.5852.510.

10. Lowbury E.J., Lilly H.A., Ayliffe G.A. (1974) Preoperative disinfection of surgeons' hands: use of alcoholic solutions and effects of gloves on skin flora. Br. Med. J., 4(5941): 369-372. doi: 10.1136/bmj.4.5941.369

11. Linton K.B., George E. (1966) Inactivation of chlorhexidine («hibitane») by bark corks. Lancet, 1(7451): 1353-1355. doi: 10.1016/s0140-6736(66)92141-6.

12. Walsh B., Blakemore P.H., Drabu Y.J. (1987) The effect of handcream on the antibacterial activity of chlorhexidine gluconate. J. Hosp. Infect., 9(1): 30-33. doi: 10.1016/01956701(87)90091-0.

13. Burdon D.W., Whitby J.L. (1967) Contamination of hospital disinfectants with Pseudomonas species. Br. Med. J., 2(5545): 153-155. doi: 10.1136/bmj.2.5545.153.

14. Hammond S.A., Morgan J.R., Russell A.D. (1987) Comparative susceptibility of hospital isolates of gram-negative bacteria to antiseptics and disinfectants. J. Hosp. Infect., 9(3): 255-264. doi: 10.1016/0195-6701(87)90122-8.

15. Russell A.D., Day M.J. (1993) Antibacterial activity of chlorhexidine. J. Hosp. Infect., 25(4): 229-238. doi: 10.1016/0195-6701(93)90109-d.

16. Richards R.M., Richards J.M. (1979) Pseudomonas cepacia resistance to antibacterials. J. Pharm. Sci., 68(11): 1436-1438. doi: 10.1002/jps.2600681127.

17. Davies D.J. (1978) Agents as preservatives in eye-drops and contact lens solutions. J. Appl. Bacteriol., 44(3): Sxix-Sxxviii. doi: 10.1111/j.1365-2672.1978.tb04191.x.

18. Hiom S.J., Furr J.R., Russell A.D. et al. (1992) Effects of chlorhexidine diacetate on Candida albicans. C. glabrata and Saccharomyces cerevisiae. J. Appl. Bacteriol., 72(4): 335-340. doi: 10.1111/j.1365-2672.1992.tb01844.x.

19. Ekizoglu M.T., Özalp M., Sultan N. et al. (2003) An investigation of the bactericidal effect of certain antiseptics and disinfectants on some hospital isolates of gram-negative bacteria. Infect. Control Hosp. Epidemiol., 24(3): 225-227. doi: 10.1086/502194.

20. Haley C.E., Marling-Cason M., Smith J.W. et al. (1985) Bactericidal activity of antiseptics against methicillin-resistant Staphylococcus aureus. J. Clin. Microbiol., 21(6): 991-992. doi: 10.1128/jcm.21.6.991-992.1985.

21. Kampf G., Höfer M., Wendt C. (1999) Efficacy of hand disinfectants against vancomycin-resistant enterococci in vitro. J. Hosp. Infect., 42(2): 143-150. doi: 10.1053/jhin.1998.0559.

22. Goroncy-Bermes P., Schouten M.A., Voss A. (2001) In vitro activity of a nonmedicated handwash product, chlorhexidine, and an alcohol-based hand disinfectant against multiply resistant gram-positive microorganisms. Infect. Control Hosp. Epidemiol., 22(4): 194-196. doi: 10.1086/503398.

23. Shimizu M., Okuzumi K., Yoneyama A. et al. (2002) In vitro antiseptic susceptibility of clinical isolates from nosocomial infections. Dermatology, 204 Suppl. 1: 21-27. doi: $10.1159 / 000057720$.

24. Guilhermetti M., Hernandes S.E., Fukushigue Y. et al. (2001) Effectiveness of hand-cleansing agents for removing methicillin-resistant Staphylococcus aureus from contaminated hands. Infect. Control Hosp. Epidemiol., 22(2): 105-108. doi: 10.1086/501872.

25. Huang Y., Oie S., Kamiya A. (1994) Comparative effectiveness of hand-cleansing agents for removing methicillin-resistant Staphylococcus aureus from experimentally contaminated fingertips. Am. J. Infect. Control., 22(4): 224-227. doi: 10.1016/0196-6553(94)99000-x.

26. Voss A., Goroncy-Bermes P. (2000) Elimination and post-disinfection transmission of Staphylococcus aureus from experimentally contaminated hands. Infect. Control Hosp. Epidemiol., 21: 106.

27. Casewell M., Phillips I. (1977) Hands as route of transmission for Klebsiella species. Br. Med. J., 2(6098): 1315-1317. doi:10.1136/bmj.2.6098.1315.

28. Marena C., Lodola L., Zecca M. et al. (2002) Assessment of handwashing practices with chemical and microbiological methods: preliminary results from a prospective crossover study. Am. J. Infect. Control., 30(6):334-340. doi: 10.1067/mic.2002.125809. 
29. Bryce E.A., Spence D., Roberts F.J. (2001) An in-use evaluation of an alcohol-based pre-surgical hand disinfectant. Infect. Control Hosp. Epidemiol., 22(10): 635-639. doi: 10.1086/501835

30. Nakahara H., Kozukue H. (1982) Isolation of chlorhexidine-resistant Pseudomonas aeruginosa from clinical lesions. J. Clin. Microbiol., 15(1): 166-168. doi:10.1128/jcm.15.1.166168.1982.

31. Barry A.L., Fuchs P.C., Brown S.D. (1999) Lack of effect of antibiotic resistance on susceptibility of microorganisms to chlorhexidine gluconate or povidone iodine. Eur. J. Clin. Microbiol. Infect. Dis., 18(12): 920-921. doi: 10.1007/s100960050434.

32. Järvinen H., Tenovuo J., Huovinen P. (1993) In vitro susceptibility of Streptococcus mutans to chlorhexidine and six other antimicrobial agents. Antimicrob. Agents Chemother., 37(5): 1158-1159. doi:10.1128/AAC.37.5.1158

33. Nakahara H., Kozukoe H. (1981) Chlorhexidine resistance in Escherichia coli isolated from clinical lesions. Zentralbl. Bakteriol. Mikrobiol. Hyg. A., 251(2): 177-184.

34. Ismaeel N., El-Moug T., Furr J.R. et al. (1986) Resistance of Providencia stuartii to chlorhexidine: a consideration of the role of the inner membrane. J. Appl. Bacteriol., 60: 361-367. doi: 10.1111/j.1365-2672.1986.tb01744.x.

35. Thomas L., Maillard J.Y., Lambert R.J. et al. (2000) Development of resistance to chlorhexidine diacetate in Pseudomonas aeruginosa and the effect of a «residual» concentration. J. Hosp. Infect., 46: 297-303. doi: 10.1053/jhin.2000.0851.

36. Martone W.J., Tablan O.C., Jarvis W.R. (1987) The epidemiology of nosocomial epidemic Pseudomonas cepacia infections. Eur. J. Epidemiol., 3: 222-232. doi: 10.1007/ BF00149728.

37. Lannigan R., Bryan L.E. (1985) Decreased susceptibility of Serratia marcescens to chlorhexidine related to the inner membrane. J. Antimicrob. Chemother., 15: 559-565. doi: 10.1093/ $\mathrm{jac} / 15.5 .559$.

38. Baillie L. (1987) Chlorhexidine resistance among bacteria isolated from urine of catheterized patients. J. Hosp. Infect., 10:83-86. doi: 10.1016/0195-6701(87)90037-5.

39. Stickler D.J., Clayton C.L., Chawla J.C. (1987) The resistance of urinary tract pathogens to chlorhexidine bladder washouts. J. Hosp. Infect., 10: 28-39. doi: 10.1016/01956701(87)90029-6.

40. Walker E.M., Lowes J.A. (1985) An investigation into in vitro methods for the detection of chlorhexidine resistance. J. Hosp. Infect., 6: 389-397. doi: 10.1016/0195-6701(85)90055-6.

41. Freney J., Husson M.0., Gavini F. et al. (1988) Susceptibilities to antibiotics and antiseptics of new species of the family Enterobacteriaceae. Antimicrob. Agents Chemother., 32(6): 873-876. doi: 10.1128/AAC.32.6.873.

42. Chawner JA, Gilbert P. (1989). Interaction of the bisbiguanides chlorhexidine and alexidine with phospholipid vesicles: evidence for separate modes of action. J. Appl. Bacteriol., 66 253-258. doi: 10.1111/j.1365-2672.1989.tb02476.x.

43. Lambert R.J., Joynson J., Forbes B. (2001) The relationship and susceptibilities of some industrial laboratory and clinical isolates of Pseudomonas aeruginosa to some antibiotics and biocides. J. Appl. Microbiol., 91: 972-984. doi: 10.1046/j.1365-2672.2001.01460.x.

44. Higgins C.S., Murtough S.M., Williamson E. et al. (2001) Resistance to antibiotics and biocides among nonfermenting gram-negative bacteria. Clin. Microbiol. Infect., 7: 308-315. doi: 10.1046/j.1198-743x.2001.00253.x

45. el Moug T., Rogers T.D., Furr J.R. et al. (1985) Antiseptic-induced changes in the cell surface of a chlorhexidine-sensitive and a chlorhexidine-resistant strain of Providencia stuartii. J. Antimicrob. Chemother., 16: 685-689. doi: 10.1093/jac/16.6.685.

46. Tattawasart U., Hann A.C., Maillard J.-Y. J. et al. (2000) Cytological changes in chlorhexidineresistant isolates of Pseudomonas stutzeri. J. Antimicrob. Chemother., 45: 145-152. doi: 10.1093/jac/45.2.145

47. Yamamoto T., Tamura Y., Yokota T. (1988) Antiseptic and antibiotic resistance plasmid in Staphylococcus aureus that possesses ability to confer chlorhexidine and acrinol resistance. Antimicrob. Agents Chemother., 32: 932-935. doi: 10.1128/AAC.32.6.932.
48. Okuda T., Endo N., Osada Y. et al. (1984) Outbreak of nosocomial urinary tract infections caused by Serratia marcescens. J. Clin. Microbiol., 20(4): 691-695. doi:10.1128/jcm.20.4.691695.1984.

49. Gandhi P.A., Sawant A.D.,Wilson L.A. et al. (1993) Adaption and growth of Serratia marcescens in contact lens disinfectant solutions containing chlorhexidine gluconate. Appl. Environ. Microbiol., 59(1): 183-188. doi:10.1128/aem.59.1.183-188.1993.

50. Tattawasart U.,Maillard J.-Y. Furr J.R. et al. (1999) Development of resistance to chlorhexidine diacetate and cetylpyridinium chloride in Pseudomonas stutzeri and changes in antibiotic susceptibility. J. Hosp. Infect., 42: 219-229. doi: 10.1053/jhin.1999.0591.

51. Westergren G., Emilson C.-G. (1980) In vitro development of chlorhexidine resistance in Streptococcus sanguis and its transmissibility by genetic transformation. Scand. J. Dent. Res., 88(3): 236-243. doi: 10.1111/j.1600-0722.1980.tb01220.x.

52. Brooks S.E., Walczak M.A. Hameed R. et al. (2002) Chlorhexidine resistance in antibiotic-resistant bacteria isolated from the surfaces of dispensers of soap containing chlorhexidine. Infect. Control Hosp. Epidemiol., 23(11): 692-695. doi: 10.1086/501996.

53. Kampf G., Kramer A. (2004) Epidemiologic Background of Hand Hygiene and Evaluation of the Most Important Agents for Scrubs and Rubs. Clin. Microbiol. Rev., 17(4): 863-893. doi: 10.1128/CMR.17.4.863-893.2004

\section{Bacterial resistance to chlorhexidine in surgical dentistry}

\section{A.G. Salmanov ${ }^{1}$, T.P. Bondar ${ }^{2}$, V.D. Chopchik ${ }^{2}$}

'Shupyk National Healthcare University of Ukraine, Kyiv, Ukraine ${ }^{2}$ Bohomolets National Medical University Center of Dental Medicine, Kyiv, Ukraine

Abstract. Antiseptic agents are increasingly used for hand hygiene and skin decolonization as key tools for the prevention of healthcareassociated infections. Chlorhexidine, a divalent, cationic biguanide, has a broad spectrum of activity and is one of the most frequently used topical antiseptic agents. Notably, there are an increasing number of prevalence studies that report reduced levels of susceptibility to chlorhexidine. In contrast to bacterial resistance to antibiotics, using parameters such as the minimum inhibitory concentration to define resistance to antiseptics, including chlorhexidine, is not straightforward. A range of methods have been used for the detection of reduced susceptibility to chlorhexidine, but, importantly, there is no standardized method and no consensus on the definition of chlorhexidine resistance. In this review we have assessed the methods available for the detection of reduced susceptibility to chlorhexidine and the prevalence of coresistance to other antimicrobial agents. We have focused on the development of reduced susceptibility to chlorhexidine and the presence of efflux-mediated resistance genes in staphylococci, and have reviewed the clinical significance of this phenomenon. Lastly, we have identified unanswered questions to further our understanding of this emergent threat. We anticipate that clinical use of chlorhexidine will continue to increase, and it will be important to be alert to the possibility that this may lead to the emergence of new clones with reduced susceptibility. Indiscriminate chlorhexidine use in the absence of efficacy data should be discouraged.

Key words: chlorhexidine; infection associated with the provision of medical care; surgical dentistry; pathogens; antimicrobial resistance.

\section{Відомості про авторів:}

Салманов Айдин Гурбанович — доктор медичних наук, професор, завідувач науково-дослідної лабораторії Національного університету охорони здоров'я України імені П.Л. Шупика, Київ, Україна.

Бондар Тарас П. — хірург-стоматолог відділення хірургічної стоматології Стоматологічного медичного центру Національного медичного університету імені 0.0. Богомольця, Київ, Україна.

Чопчик Віталій Д. - доктор медичних наук, професор, завідувач відділення хірургічної стоматології Стоматологічного медичного центру Національного медичного університету імені 0.0. Богомольця, Київ, Україна.

\section{Адреса для кореспонденції:}

Салманов Айдин Гурбанович

04112, Київ, вул. Дорогожицька, 9

E-mail:mozsago@gmail.com
Information about the authors:

Salmanov Aidyn G. - MD, Dr. Sc., Full Professor, Head of the Scientific Research Laboratory of Shupyk National Healthcare University of Ukraine, Kyiv, Ukraine.

Bondar Taras P. - Surgeon Dentist of Surgical Dentistry Department of Bohomolets National Medical University Center of Dental Medicine, Kyiv, Ukraine.

Chopchik Vitaly D. - MD, Dr. Sc., Professor, Head of Surgical Dentistry Department of Bohomolets National Medical University Center of Dental Medicine, Kyiv, Ukraine.

\section{Address for correspondence:}

Aidyn Salmanov

04112, Kyiv, Dorohozhytska St., 9

E-mail:mozsago@gmail.com 